\title{
DAMPAK PUNGUTAN PAJAK DILIHAT DARI SEGI HUKUM, EKONOMI DAN SOSIOLOGI
}

\author{
Hamja \\ Universitas Wiralodra, Indramayu \\ Email: hamja.hamja904@unwir.ac.id
}

\begin{abstract}
Tax is a mandatory contribution for people who have fulfilled the entry requirements to become taxpayers. The tax is expected to improve the welfare of all people. The tax cannot be felt directly by the community. The implementation of tax collection must have a clear regulation. The purpose of this article is to determine the impact of tax collection in terms of the economy perspective; to know the impact of tax collection if viewed from a legal perspective; to know the impact of tax collection if viewed in terms of sociology. The results of the study indicate that Article 1 of Law Number 6 of 1983 in conjunction with Law 28 of 2007, the definition of tax is a mandatory contribution to the State owed by an individual or entity that is compulsory based on the Law, by not receiving direct compensation and used for State needs for the greatest prosperity of the people. Tax is one of the sources of government revenue. It means that the increase in tax collection directly increases government revenues. Thus, the tax has several functions, namely the function of the budget (budgetair) and the regulating of function (regurelend).
\end{abstract}

\section{Keywords : legal perspective, impact, tax,}

\section{PENDAHULUAN}

Pajak merupakan suatu iuran wajib bagi masyarakat yang telah memenuhi syarat masuknya menjadi wajib pajak. Adanya pajak diharapkan akan meningkatkan kesejahteraan hidup semua masyarakat. Pajak tersebut sifatnya tidak dapat merasakan manfaatnya secara langsung oleh masyarakat. Dalam pelaksanaan pemungutan pajak harus memiliki aturan yang jelas. Oleh karena itu, pemungutan pajak di Indonesia diatur dalam Undang-Undang tentang Perpajakan, antara lain Undang-Undang Nomor 28 Tahun 2007 tentang Ketentuan Umum dan Tata Cara Perpajakan (KUP). Berdasarkan pasal 1 Undang-Undang Nomor 6 Tahun 1983 jo Undang-Undang 28 Tahun 2007, pengertian pajak adalah kontribusi wajib kepada Negara yang terutang oleh orang pribadi atau badan yang bersifat memaksa berdasarkan Undang- 
Undang, dengan tidak mendapatkan imbalan secara langsung dan digunakan untuk keperluan Negara bagi sebesar-besarnya kemakmuran rakyat.

Pemungutan pajak harus dijalankan menurut hukum agar pemerintah (petugas pajak) tidak bertindak sewenang-wenang dalam menetapkan dan memungut pajak. Pentingnya pajak diatur dalam suatu undang-undang sebelum dilakukan pemungutan pajak didasarkan pada kepastian hukum. Dalam hal ini, pungutan pajak Negara terhadap masyarakat akan berdampak pada berbagai segi seperti halnya perekonomian, hukum dan sosiologi.

\section{A. Rumusan Masalah}

a. Apakah dampak pungutan pajak terhadap masyarakat dari segi ekonomi?

b. Apakah dampak pungutan pajak jika dilihat dari segi hukum dan sosiologi?

\section{B. Tujuan}

a. Untuk mengetahui dampak pungutan pajak jika dilihat dari segi ekonomi

b. Untuk mengetahui dampak pungutan pajak jika dilihat dari segi hukum dan segi sosiologi.

\section{HASIL DAN PEMBAHASAN}

\subsection{Dampak Pungutan Pajak Dilihat Dari Segi Ekonomi}

Dampak langsung dari pungutan pajak adalah pada pendapatan disposibel. Pendapatan disposibel adalah pendapatan pribadi dikurangi dengan pajak. Pendapatan disposibel merupakan pendapatan yang dapat dibelanjakan untuk konsumsi. Ketika pungutan pajak dinaikkan, maka pendapatan disposibel relatif menjadi turun. Dengan menurunnya pendapatan disposibel maka konsumsi relatif menjadi turun. Turunnya konsumsi akan berdampak pada turunnya pendapatan nasional 
equilibrium. Demikian pula, jika pungutan pajak diturunkan, maka konsumsi relatif menjadi naik. Naiknya komponen ini dapat menaikkan pendapatan nasional. Tentu saja dengan hal ini asumsi jika komponen lain yang berpengaruh terhadap pendapatan nasional tidak berubah.

Pajak merupakan salah satu sumber pendapatan pemerintah. Artinya peningkatan pungutan pajak secara langung meningkatkan pendapatan pemerintah. Dengan demikian jika pendapatan dari pajak ini digunakan untuk pengeluaran yang berpengaruh terhadap nilai komponen pengeluaran pemerintah, maka peningkatan pungutan pajak dapat berpengaruh terhadap peningakatan nilai pembelian oleh pemerintah. Dalam hal ini, pungutan pajak berkorelasi dengan komponen pemerintah, karena komponen pemerintah berkorelasi positif dengan Gross Domestic Product (GDP), maka setiap kenaikan pungutan pajak dapat meningkatkan kenaikan GDP.

\subsection{Dampak Pungutan Pajak Dilihat Dari Segi Hukum}

Dasar hukum pengenaan pajak diatur dalam ketentuan pasal 23 ayat (2) UUD 1945 Amandemen ke-5 juga UU Nomor 28 tahun 2007 tentang KUP. Pajak dari perspektif hukum merupakan suatu perikatan yang timbul karena adanya undang-undang yang menyebabkan timbulnya kewajiban warga negara untuk menyetorkan sejumlah penghasilan tertentu kepada Negara, Negara mempunyai kekuatan untuk memaksa dan uang tersebut harus dipergunakan untuk penyelenggaran pemerintahan. Pemungutan pajak harus dijalankan menurut hukum agar pemerintah (petugas pajak) tidak bertindak sewenang-wenang dalam menetapkan dan memungut pajak. Pentingnya pajak diatur dalam suatu undang-undang sebelum dilakukan pemungutan pajak didasarkan pada kepastian hukum.

Maka dampak pemungutan pajak menurut hukum yang mana menyangkut legalitas, peraturan dan ketentuan serta dasar hukum dan implikasi hukumnya yang mana lebih menitikberatkan pada segi hukum 
tentang hak dan kewajiban fiskus (pemungut pajak) maupun wajib pajak, prosedur pemenuhan kewajiban perpajakan dan prosedur pengajuan hakhak wajib pajak, saat timbul dan hapusnya utang pajak.

Berdasarkan hal diatas, maka pajak mempunyai beberapa fungsi, yaitu fungsi anggaran (budgetair) dan fungsi mengatur (regurelend).

\section{Fungsi anggaran}

Sebagai sumber pendapatan Negara, pajak berfungsi untuk membiayai pengeluaran-pengeluaran untuk Negara. Untuk menjalankan tugs-tugas rutin Negara dan melaksanakan pembangunan, Negara membutuhkan sumber pembiayaan. Sumber pembiayaan ini salah satunya dapat diperoleh dari penerimaan pajak. Pajak digunakan untuk membiayai pengeluaran rutin Negara, seperti belanja barang, belanja pegawai, belanja pemeliharaan, dan lain sebagainya.

\section{Fungsi mengatur}

Pemerintah dapat mengatur kebijakan di bidang ekonomi dan sosial melalui kebijakan fiskal. Dalam menjalankan fungsi mengatur, pajak dapat digunakan sebagai alat untuk mencapai tujuan Negara. Contohnya, dalam rangka mendorong penanaman modal baik dalam negeri maupun luar negeri, diberikan berbagai macam fasilitas keringanan pajak. Dalam rangaka melindungi produksi dalam negeri, pemerintah menetapkan bea masuk yang tinggi untuk produk luar negeri.

\section{Dampak Pungutan Pajak Dilihat Dari Segi Sosiologi}

Pemungutan pajak dalam lingkungan masyarakat dari segi sosiologi menimbulkan suatu akibat yang timbul dari pungutan pajak dan apa hasil yang diterima oleh masyarakat dari pungutan wajib pajak tersebut, sehingga dari hasil pungutan pajak tersebut diharapkan bias membiayai pembangunan nasional secara merata di masyarakat. 
Pemerintah telah menyusun program untuk pengalokasian dana dari pungutan pajak tersebut salah satuya melalui pemberian subsidi kepada masyarakat untuk mengurangi beban masyarakat. Hal tersebut, sebenarnya masyarakat sudah menikmati uang pajak yang mereka bayarkan, tanpa diketahui sebelumnya. Pemerintah sampai saat ini masih memberikan subsidi untuk sektor-sektor tertentu yang sangat mempengaruhi hajat hidup orang banyak, mulai dari subsidi Bahan Bakar Minyak (BBM), subdisi listrik, bantuan langsung sementara masyarakat (BLSM) atau sejenisnya, pengadaan beras miskin (raskin), jaminan kesehatan masyarakat (jamkesmas), pembangunan sarana umum seperti jalan, jembatan, sekolah, rumah sakit, puskesmas dan pembiayaan lainnya dalam rangka meningkatkan kesejahteraan bagi seluruh lapisan masyarakat.

\section{Kesimpulan}

Menurut pasal 1 Undang-Undang Nomor 6 Tahun 1983 jo UndangUndang 28 Tahun 2007, pengertian pajak adalah kontribusi wajib kepada Negara yang terutang oleh orang pribadi atau badan yang bersifat memaksa berdasarkan Undang-Undang, dengan tidak mendapatkan imbalan secara langsung dan digunakan untuk keperluan Negara bagi sebesar-besarnya kemakmuran rakyat.

Pajak merupakan salah satu sumber pendapatan pemerintah. Artinya peningkatan pungutan pajak secara langung meningkatkan pendapatan pemerintah. maka pajak mempunyai beberapa fungsi, yaitu fungsi anggaran (budgetair) dan fungsi mengatur (regurelend).

1. Fungsi anggaran

Sebagai sumber pendapatan Negara, pajak berfungsi untuk membiayai pengeluaran-pengeluaran untuk Negara.

2. Fungsi mengatur 
Pemerintah dapat mengatur kebijakan di bidang ekonomi dan sosial melalui kebijakan fiskal. Dalam menjalankan fungsi mengatur, pajak dapat digunakan sebagai alat untuk mencapai tujuan Negara.

\section{DAFTAR PUSTAKA}

http://www.jdih.kemenkeu.go.id/fullText/2007/39TAHUN2007UUPenj.htm

Diakses tanggal 13 September 2018

https://www.cermati.com/artikel/manfaat-pajak-bagi-masyarakat-dan-negara

Diakses tanggal 13 September 2018

https://ekonomi.bisnis.com/read/20190411/259/910587/opini-kebajikan-dalampungutan-pajak Diakses tanggal 13 September 2018

https://www.kompasiana.com/didikyandiawan/550eab3f813311c12cbc66ac/eduka si-perpajakan-1-kedudukan-pajak-dalam-tatanan-sosial Diakses tanggal 13 September 2018 